\title{
Inclusion of Roma Children into Education in Slovenia: The Language Competence and Culture Dimensions
}

\author{
Albina Nećak Lük* and Sonja Novak Lukanovič
}

\author{
Faculty of Arts, University of Ljubljana, Aškerčeva 2, SI-1000 Ljubljana, Slovenia
}

\begin{abstract}
Language and culture variables strongly intervene in the social inclusion process in education. Grater rate of school failure and higher numbers of school out-drops of children from minority groups can be attributed to the language competence issues, and, at least when Roma children are concerned, also to the cultural mismatch. Allocation of languages as media of instruction and as subjects of curriculum, contributing to either social inclusion or exclusion, is strongly dependent on a country's language policy strategy. On the one hand, in the educational process, (depending on the nature of the school programme in view of "strong", i.e. minority language supporting or "weak", i.e. minority language stigmatizing" models), the learner's native tongue can be taken into consideration or disregarded. On the other hand, in many cases, an appropriate didactic approach to the L2 teaching and learning, i.e. to acquisition of the language of instruction, is systematically lacking. Proficiency in L1 and L2 being a strong factor with both, the school achievement as well as the integration of minority children, they are deprived on both dimensions when the language issues are disregarded or inappropriately treated.

The study is focused on the language aspects of the inclusion of Roma children into the Slovene school system. After theoretical frame on the role of language(s) in social inclusion, a brief insight into the policy of social inclusion in education in Slovenia in general, as presented in legal and basic strategy documents, is followed by discussion of the inclusion documents related to the Roma community, rounded up by presentation of mayor findings of studies and projects dealing primarily with the language dimension of the inclusion of the Roma in education. The effectiveness of the prescribed measures is illustrated by pointing to the findings of evaluation studies and projects. In concluding remarks, an attempt is made to draw out some possible recommendations regarding the language dimension of the social inclusion of Roma children in education.
\end{abstract}

Keywords: Minority education, Social inclusion, Language competence, Culture, Legislation, Projects, Roma, Slovenia.

\section{INTRODUCTION}

For over five decades now, the educational models for both national minorities, the Italian language school and the bilingual Slovene-Hungarian one, figure as an integral part of the educational system of the Republic of Slovenia. They have been proven successful with regard to the language maintenance and ethnic identity transfer as well as with regard of social inclusion of members of both minorities into the mainstream society. On the other hand the search for optimal systemic and practical solutions for social inclusion of Roma and migrant children have been in course for some decades now [1]. In the last decade the most relevant outcome of this search is reflected in the fact that the language and culture dimensions have found their proper place among the crucial factors for effective social inclusion of these children into education.

The present study furnishes an insight into the policy of social inclusion of Roma pupils in education in Slovenia. First some theoretical deliberations on the role of language competence (in L1 and L2) and cultural issues as important intervening factors in the social inclusion process are exposed. Next, some general information on the Roma

*Address correspondence to this author at the Faculty of Arts, University of Ljubljana, Aškerčeva 2, SI-1000 Ljubljana, Slovenia; Tel: 00386 12411428; Fax: 00386 12510964; E-mail: albina.necak@guest.arnes.si community in the Republic of Slovenia together with some indices on the situation of Roma children in schools should provide the reader with some background data for a better understanding of the policy measures. Presentation of legal framework and discussion of the inclusion documents related to the Roma community, in which language and culture issues are also dealt with due attention, is rounded up by presentation of mayor findings of studies and projects dealing with the language (and culture) aspect of inclusion of the Roma in education. The effectiveness of the prescribed measures is illustrated by short summaries of some evaluation studies/projects, followed by some conclusive remarks and references.

\section{LANGUAGE AND CULTURE AS SOCIAL INCLUS- ION ISSUES IN EDUCATION}

The issue of language education policy is of extreme relevance when social integration of the minority, i.e. also Roma children is dealt with. In the framework of favourable conditions and environment for social inclusion, culture and language factors play the role of an important intervening variable. Therefore promotion of the language and culture of minority groups through appropriate language education policy can be considered a mile stone in their over-all social inclusion, language competence being one the key factors for their access to the labour market on equal terms. 
The language competence role in the social inclusion is the matter of a multi-facet effect. On the one hand, mother tongue is an essential feature of ethnic identification and an important means of intergenerational ethnic continuity. It is transmitted to younger generations through the process of socialisation in which formal (school) education plays a major role. On the other hand, competence of the second language, which is essential for efficient integration into the society, is of special relevance for success of an individual in the labour market as well as for social mobility.

As recent sociolinguistic and psycholinguistic research show, language is one of the crucial factors influencing a child's academic development: discrepancies between the pupil's mother tongue and the language of instruction, accompanied by inappropriate didactic approach, can be detrimental to a child's cognitive as well as to his/her overall development [2]. Deficient competence of both languages, the first and the second, are quite widely spread outcomes in such situations, known as the semi-lingualism [3].

Accordingly, language and culture variables strongly intervene in the social inclusion process. Grater rate of school failure and higher number of school out-drops of children from minority groups can be attributed to the language competence issues, and (at least when Roma children are concerned) also to the cultural mismatch. Allocation of languages as media of instruction and as subjects of curriculum, contributing to either social inclusion or exclusion, is strongly dependent on a country's language policy strategy; in the educational process learner's native tongue can be taken into consideration or disregarded and even stigmatized.

The significance of culture and language in promotion of social inclusion and in creating equal economic opportunities for different ethnic groups has not yet been fully recognised neither in the EU nor national strategies and documents.

One of the appeals for taking into consideration the cultural and language factors as the social inclusion issues of minority groups was launched by the European Commission: “...the European Commission has recently drawn attention to the importance of culture in promoting the inclusion of ethnic minorities and immigrants and has identified culture as a key policy area to be assessed and evaluated, ${ }^{1}$ arguing that access to cultural activity is a core part of human existence and is thus crucial for fostering a positive sense of identity. In its report of March 2004, the Commission emphasized cultural policies as a central part of any approach to addressing social exclusion and highlighted the aspect of culture in promoting social inclusion in countries with high immigration [4]."

The overview of documents, different materials and research results show that in Slovenia compared to other EU countries the problem of social exclusion is not an outstanding problem, (yet). The share of primary school pupils continuing their education at the secondary level amounted to $98 \%$ in $2001 / 2002$, and $75,4 \%$ of the generation completed secondary school in 2000. Barle Lakota et al. [5]: p.1. However, there are certain groups that appear more vulnerable than others. Young people who leave education without recognized qualifications are at a disadvantage in the labour market. Moreover, certain groups of early school leavers are likely to experience greater disadvantage than others, in particular those who leave the system before completion of primary education. Adults learn better in a non-competitive environment where they can work together with others and where they are in control of their learning processes. They are more motivated when they acquire knowledge and skills in a situation where their self-respect is not at risk. The learning climate is important; age and life experience are aspects that should be taken in consideration when developing learning environments. This is particularly relevant when additional socio-cultural differences come into interaction with traditional school approach and expectations, as ethnic, linguistic, religious. Therefore it is worth noting that in the Republics of Slovenia National Report on Strategies for Social Protection and Social Inclusion 2008 - 2010 from September 2008 due attention is given to the language and culture dimension of social inclusion of Roma as well as of migrants.

\section{INCLUSION OF ROMA CHILDREN}

In the past, in Slovenia three possible ways of inclusion of Roma children into kindergarten and elementary school were practiced:

- Homogeneous classes, formed in the beginning of schooling, attended by Roma children,

- Partly homogeneous classes, where Roma children attended only homogenous classes of Slovene language, mathematics and natural plus social science, while in other classes they were together with other pupils,

- Heterogeneous, i.e. mixed classes with Roma and non-Roma children attending all classes together.

- $\quad$ Some schools had also so called group work without formal classes, where Roma children from different classes were joined into special groups for the study of mathematics, Slovene language and natural plus social science, which was supposed to contribute to better success and higher motivation. [6]: p.61.

The three approaches mentioned above had been practiced in a number of individual elementary schools. As proven by their experience as well as by educational research homogenous Roma classes did not achieve the desired effect.

Early integration of Roma children into heterogeneous departments at the very beginning of a kindergarten and elementary school attendance proved to be the best choice. Several reasons can be enumerated in favour of integrated classes and against segregating children on the basis of ethnic adherence. Possibility of spontaneous learning among children, developing respect for each other's culture and language are among them. In such classes, cultural pluralism and pluri-lingualism as two crucial European concepts can be practiced in vivo.

${ }^{1}$ European Commission, "Community Action Programme to Combat Social Exclusion, 2002-2006: Evaluation of the Impact of Inclusion Policies under the Open Method of Coordination", Call for Proposals, VP/2005/009. 
Since the school year 2003/2004 there is no legal basis for homogenous classes in Slovenia. ${ }^{2}$ Roma children in all schools are integrated into heterogeneous classes, which is supposed to have a favourable effect in the future.

\subsection{Background Information}

The majority of Roma in Slovenia are settled in the Dolenjska and Prekmurje region. There is also an almost extinct group of Sinti in the Gorenjska region. The Dolenjska and the Prekmurje Romas are considered an autochtonous Roma community. (The term autochotnous is used to designate the minority groups whose presence in the Slovene territories had been registered in the distant past.)

The first official mentioning of the Romas in Prekmurje goes back to 1681 , when a Roma child was matriculated in the Parish register of Bogojina. The Roma groups of the Dolenjska and Prekmurje region are considered autochtonous regardless of whether they are settled (which is the case of the majority of Roma in Slovenia) or they still choose a nomadic way of life. On the other hand, Roma groups that had recently (i.e. in the last decades) moved into Slovenia, and live - more or less settled - in the suburbs of some Slovenian towns (estimated at 1300 persons only in Ljubljana, the capital of Slovenia) are not attributed the status of an autochtonous community. Since the provisions of the Roma Community Act pertain only to Roma groups that are considered autochtonous, i. e. the Dolenjska and Prekmurje Romas, the "new-coming" Romas are deprived of the rights proceeding from the Act. This fact has attracted the attention of the UNO human right bodies as well as that of the Council of Europe and the Slovenian Constitutional Court, which claim that differentiating Romas along the autochtonous and non-autochtonous line is not in concordance with either the Slovene Constitution or the human rights principles [7].

Owing to the 2002 population census there were 3246 persons in Slovenia who declared Roma as their ethnic adherence and 3834 persons who claimed their language was Romani. Unofficial estimates, however, raise their number to

${ }^{2}$ Primary Schools Act (Off. Gaz. of the RS, No. 70/05, 60/06) determines in Art. 40, in which forms of differentiation are described:

From 1. to 9. grade teachers in instructions and other forms of organized work differentiate lecture with pupils according to their capabilities (inner differentiation);

From grade 4 to 7 it is possible (in the extent of $25 \%$ of lessons) to organize level instruction with mathematics and with Slovene, Italian and Hungarian languages in the ethnically mixed territories, as well as with the foreign language (flexible differentiation);

In grades 8 and 9 lessons of Slovene, Italian and Hungarian in the ethnically mixed territories, as well as with mathematics and foreign language, can be organized in the following ways:

a) By distributing pupils into groups of instruction

b) By simultaneous lecturing of 2 teachers

c) As level instruction

d) As combination of differentiation forms from the above

e) the number of lectures, dedicated to implementation of differentiation in grades 8 and 9 must be the same, regardless of the form of differentiation, that is being implemented

Schools gained autonomy by this law, as the decision on the implementation of forms of differentiation in the second (grades 4-7) and the third (grades 8 and 9) periods, proposed by headmaster, is adopted by the school council as a rule for 1 school year. Before the decision the school council obtains the opinion of teachers' and parents' councils. Any of the above options can be chosen to help the Roma children in consistence with the nature of their need. Among others, Roma assistant proved to be among optimal solutions. between 6 and 10 thousand. Owing to the 2002 census, in the generation under 19 years there were 1478 persons, 717 of them were of the obligatory school age (between 6 and 15; Table 1). ${ }^{3}$

\section{Table 1. Roma Children of School Age and Below}

\begin{tabular}{|c|c|}
\hline Age & Number \\
\hline \hline $0-4$ & 454 \\
\hline $5-9$ & 364 \\
\hline $10-14$ & 353 \\
\hline $15-19$ & 307 \\
\hline
\end{tabular}

Source:Statistical Office of the Republic of Slovenia, Census of Population, Households and Housing, 2002. Use and publication of data is allowed provided the source is acknowledged.

It is a well known fact that in any society (state) the process of the Roma integration is a complex and long lasting endeavour; owing to their predominantly nomadic way of life the inclusion of the Roma children in the educational system is a demanding scheme. For several decades now Slovenia has dedicated considerable efforts to the integration of the Roma, one of the ways being also the inclusion of their children into educational system. While in Prekmurje the level of integration is reasonably satisfactory the beginnings of systematic integration of the Prekmurje Romas goes back to the sixties of the past century, systematic local attention being paid to this cause for decades (based also on research into their way of life, attitudes and perceptions) - the integration of Roma in the Dolenjska region lags behind, accompanied by many conflicts between them and the non-Roma local population [8]. This fact is also reflected in the inclusion of the Roma children in schools: in 2008 there was a $90 \%$ inclusion in the Prekmurje and $39 \%$ in the Dolenjska region. ${ }^{4}$

Although a positive trend can be traced between the last two population censuses (1991 and 2002) with regard to the growth of educational level of Romas, the rise is very gradual and essentially lower than the progress of Slovenes [9]. Proof of the fact that integration of the Roma children in the educational process is less than satisfactory may be found in the comparison and in the fact that the share of the Roma children, who successfully progress in the education vertical, is still essentially lower in comparison with the rest of Slovenia's population (Fig. 1). The fact that the census data are related only to approximately one third of the estimated Roma population in Slovenia, maybe allows for a more optimistic conclusion (or not?).

\subsection{Legal Frames of the Roma Inclusion into Education}

In concordance with the Slovenian Constitution request, ${ }^{5}$ the Roma Community Act was adopted in $2007,{ }^{6}$ by which

\footnotetext{
3 See also pages http://www.stat.si/eng/novica_prikazi.aspx?id=1160-, http://www.uvn.gov.si/en/minorities_national_communities/roma_ethnic_co mmunity/

${ }^{4}$ Radio News Val 202, 26. 1. 2009.

${ }^{5}$ Article 65 of the Constitution of the Republic of Slovenia stipulates: "The status and special rights of the Roma Community living in Slovenia shall be regulated by law."
} 


\section{SETTLEMENTS OF ROMA IN SLOVENIA}

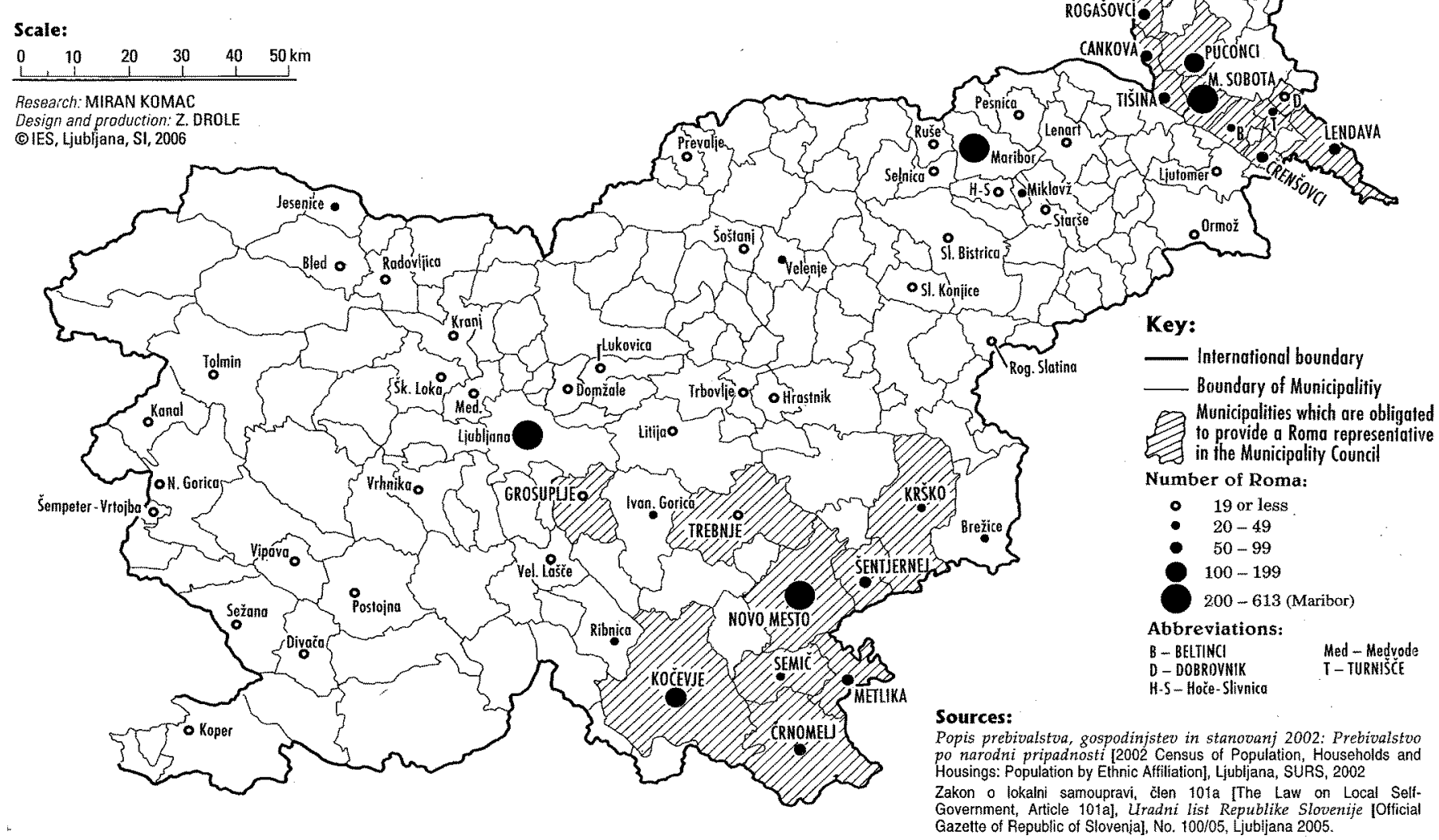

Map 1. Territorial Distribution of Roma Population in Slovenia, 2002 Population Census.

special rights are granted to the members of the Roma community in the field of education, culture, employment, space managing, health and social care, information and participation in decision making. In this vein Republic of Slovenia is obliged to create appropriate conditions for social inclusion of the Roma community members by consecrating a special attention to:

- Raising the education level by intensifying the inclusion into the educational system and by appropriate scholarship policy;

- $\quad$ Stimulating professional education, qualification and the employment;

- $\quad$ Promoting the maintenance and development of the Romani language and the cultural, information and editorial activities of the Roma community.

In this context the establishment of the Roma Community Council in the Republic of Slovenia (Svet romske skupnosti RS) is of special importance, providing for the inclusion of the Roma representatives, and through them also the wider Roma community into the decision making process on their developmental issues. Thus the following tasks related to education and language are listed in the Council's regulations: ${ }^{7}$

${ }^{6}$ Act on the Roma Community in the Republic of Slovenia, Official Gazette, No. 33/2007, p.4602.

${ }^{7}$ Article 10 of the Regulations of the Roma Community Council of the Republic of Slovenia, Official Gazette, No. 94/2007, p. 12806
- Discussing and framing proposals and initiatives related to the Roma community rights and status;

- Active participation in the developmental programmes realisation, especially those related to Roma issues;

- Dealing with the Romani language and the Roma culture maintenance issues;

- Attending to the maintenance of the Roma community's identity and specific features, especially in the field of socialization and education of Roma children, development of the Roma cultural and information activities;

- $\quad$ Stimulating participation of the Roma community members in the decision making about their special rights;

Active participation is granted also on the local level, where in concordance with the local self-government legislation a Roma representative is elected into the Municipality Council of the municipalities where they live (in 19 of 210 municipalities). For assessing of the Roma community's position, a special working body with a majority of the Roma members is established at the Municipality Council, in concordance with the article 7 of the Roma community act. 


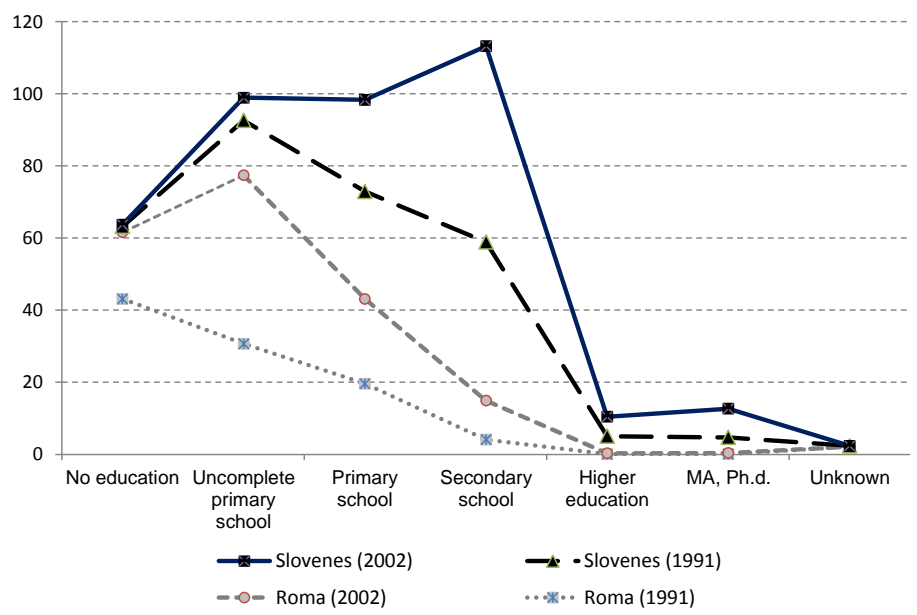

Fig. (1). Comparison of education structure amongst population above 15 years of age, declared as the Roma and Slovenes in the 1991 and 2002 population census; in \% (Source: Statistical Office of the Republic of Slovenia, Population Census 1991, 2002) ${ }^{8}$.

Protection of special rights of the Roma Ethnic Community is currently being implemented through sectorspecific acts:

1. Local Self-Government Act (Official Gazette RS, No. $72 / 93, \ldots, 100 / 05)$,

2. Local Elections Act (Official Gazette RS, No. 72/93, $\ldots, 22 / 06)$,

3. Voting Rights Register Act (Official Gazette RS, No. 52/02, 11/03, 73/03),

4. Act on Enforcing Public Interest in the Field of Culture (Official Gazette RS, No. 96/02),

5. Organisation and Financing of Education Act (Official Gazette RS, No. 12/96, ..., 98/05),

6. Kindergarten Act (Official Gazette RS, No. 12/96, ..., 100/05),

7. Elementary School Act (Official Gazette RS, No. $12 / 96, \ldots, 70 / 05)$,

8. Public Media Act (Official Gazette RS, No. 35/01, $\ldots, 96 / 05)$,

\subsection{Education Legislation and Documents}

In 1996, with the educational reform the legal basis for special conditions governing the education of Roma children was incorporated in the reformed education legislation, and the Organisation and Financing of Education and Training Act, ${ }^{9}$ Kindergarten Act ${ }^{10}$ and Elementary School Act ${ }^{11}$ were additionally amended from 2000 onwards.

\section{${ }^{8}[4]$}

${ }^{9}$ The Act on organizing and financing of education in Article 25 states, among competences of the Expert Council of the RS for general education, formation of program of supplementary education for Roma children. Article 81 states that the state budget ensures »means for preparation and subsidizing of prices of primary school textbooks and learning materials, for national communities' education and education of Slovene minority members abroad and emigration, and for Roma « and »a part of the means for primary school education for Roma«. Article 84 states that the Minister determines special norms and standards for education of Roma children.

${ }^{10}$ Article 7 states that pre-school education of Roma children be performed in accordance with this law and other regulations. The chapter on transitory and final provisions states in Article 54 that for public service in the sphere
In 2002, the Supplement to the Kindergarten Curriculum for working with Roma children ${ }^{12}$ was adopted, which defines the approaches for kindergarten teachers in the creation of conditions for the implementation of rights of Roma children to equal opportunities in education. The Supplement states that in the formation of practical curricula for the work with Roma children in kindergartens, the following principles and aims are of special importance:

- $\quad$ The principle of openness of curriculum, autonomy and professional responsibility of the kindergarten staff (search for elements of Slovene and Roma culture);

- The principles of equal opportunities, respect for diversity, principle of multiculturalism;

- Experiencing kindergarten as an environment, offering equal opportunities for integration into activities and daily life, regardless of gender, physical and mental constitution, national adherence, cultural origin, religion, etc. (diversity of children - wealth for kindergartens);

- $\quad$ The principle of cooperation with parents;

- The principle of active learning and ensuring the possibility of verbalizing and other manners of expression [6].

In 2000 new Instructions for the implementation of nineyear primary school program for Roma pupils were adopted, ${ }^{13}$ emphasising the need to apply modern

of pre-school education and primary school preparation of children, the programs for pre-school Roma children can also be included until programs for pre-school children be adopted according to this law (in the mean time in December 2002, the Expert Council of the RS already adopted the Supplement to the Curriculum for Kindergartens for the work with Roma children). The means for its implementation are drawn from the state budget.

${ }^{11}$ Article 9: »Primary school education of Roma community members in the $\mathrm{RS}$ is performed in accordance with this law and other regulations."

${ }^{12}$ Available from http://www.mju.gov.si/fileadmin/mss.gov.si/pageuploads/podrocje/vrtci/pdf/ vrtci_Dodatek_-_ROMI.pdf (June 1, 2006).

${ }^{13}$ Instructions for work in educational institutions that integrate minority children and Roma are adopted by the RS Expert Council for General Education. 
methodological and didactic approach instead of lower demands for Roma children knowledge.

In May and June 2004 the "Strategy for Education of Roma in the Republic of Slovenia" was adopted by all three Professional Councils of the Republic of Slovenia for Education (for general education, vocational and professional education and for adult education). ${ }^{14}$ Participation of the Roma members in the process of the Strategy preparation is worth noticing, namely in concordance with provisions of the Roma Community Act, the Roma community was represented in the working group. The main challenge of the Strategy is to promote the integration of the Roma children into school by respecting their way of life, tradition and culture. The strategy is based on the principles of modern intercultural learning and is in concordance with the Council of Europe's and the European Union's concepts of educational policy striving for improvement of status of the Roma communities.

The Strategy document sets an important message upon the government by claiming that the quality and possibilities of Roma children education are also affected by other social factors and living conditions, such as housing, etc., on which kindergartens and schools can have no direct impact. "That is why for the improvement of inclusion of Roma children in the educational system, cooperation of different ministries is of utmost importance (Ministry of Education and Sport, Ministry of University Education, Science \& Technology (scholarships), Ministry of Labour, Family and Social Affairs (social and family aid possibilities, scholarships, public works in education programs, vocational training programs), Ministry of Health (educational programs for nurses and home nursing, survey and possible supplements of legal foundations for necessary evidence, co-financing of research projects on links between lifestyle, health and education) and institutions at national level (National Education Institute, RS Centre for Vocational Training, Adult Education Centre of the RS, Health Protection Institute, Health Care Centre of the RS, Employment Service of the RS, Chamber of Commerce of the RS, Chamber of Trades of the RS, different local institutions and Roma Association of Slovenia".

It is important to notice that the measures and priorities put forward in the Strategy are based on the results of continuous, long lasting research, analyses and reports on the integration of Roma children into the mainstream education, prepared under the auspices of the Ministry of Education and Sport.

In the Strategy for education of the Roma in the RS, measures are defined with which more effective inclusion of Roma pupils into the educational system is to be obtained:

\footnotetext{
${ }^{14}$ Strategija vzgoje in izobraževanja Romov v Republiki Sloveniji [Strategy for education of the Roma in the Republic of Slovenia] (2004). Working group: Andreja Barle Lakota [et al.]. Ljubljana: Ministry of Education and Sport. Available from http://www:mju.gov.si/fileadmin/mss.gov.si/page uploads/podrocje/razvoj_solstva/projekti/enake_moznosti/0721_strategija_R omi.doc [May 30, 2009].
}

- Additional financial means for individual or team work with Roma pupils are reserved, ${ }^{15}$

- More favourable standards for classes with Roma have been adopted, ${ }^{16}$

- $\quad$ Food, ${ }^{17}$ textbooks, ${ }^{18}$ and excursions for Roma pupils are separately financed,

- $\quad$ Financing of the first exercise book for the teaching of Roma language,

- Within the National Education Institute a team of teachers specialized in teaching Roma pupils was formed [6].

Each year a National actions plan, prepared by a special working group of the ministry, is adopted. The adopted solutions are to be executed through projects in the framework of the new financial perspective of the European social fund - Operative program of the human sources development $2007-2013$.

The following goals aiming at better integration of the Roma children into the educational system are put forward by the Strategy:

- Early inclusion of Roma children in pre-school institutions, at least two years prior to their enrolment in elementary school, (i.e. when they are four years of age at the latest). The principal purpose of Roma children's inclusion in pre-school institutions is learning both Slovene and Roma language and with this earlier socialisation in an educational institution, which would help a child to an easier accommodation in the elementary school.

- The appointment of a Roma assistant to the classes with Roma children which should help to surmount the emotional and language barrier; he/she would represent a kind bridge between the kindergarten/school and the Roma community.

- Content adjustment of curriculum: introduction of the Romani language lessons in elementary school as an optional subject in the elementary school; application of an appropriate teaching approach to the Slovene as the second language; contents related to the Roma culture, history and identity.

\footnotetext{
${ }^{15}$ In school year 2003/04, the Ministry granted schools 512 hours for small group lessons; this form of help is according to schools absolutely necessary for successful work with Roma pupils.

${ }^{16}$ Within norms and standards for primary schools, valid till the end of school year 2002/2003, special norms were defined for the formation of Roma classes and classes including Roma children; since 2003/2004 norms no longer anticipate formation of Roma classes. The norm for a class containing at least 3 Roma pupils is 21 .

${ }^{17}$ The Ministry for education and sport increases the means for the subsidizing of school meals to all primary schools, including Roma pupils.

${ }^{18}$ Primary schools are allotted by the MES 5,17 EUR per month per Roma pupil as an assistance in the covering of expenses of school materials, transports, entrance fees to cultural, biological, sports events, etc. Schools are autonomous in the finance distribution and with the co-financing of additional material expenses of Roma pupils, particularly considering the following criteria: social financial aid distribution according to regulations on social care, the amount of income per family member, the amount of family allowance, unemployment of parents, long-term illness in family, long-term social problems, and other specific features [10].
} 
- Permanent in-service training and additional education programs for teachers and other professionals.

- $\quad$ Non-segregation, i.e. integration of Roma pupils etc.

- $\quad$ Establishing a trustful atmosphere in school and antibias activities: each school prepares a plan of communication activities and cooperation with the Roma parents, and a plan for suppressing the stereotypes and prejudices of the majority population against Roma pupils.

-

Adult education: four years of secondary education is considered the basic educational standard, to promote employment and permanent life-long learning of the adult Roma population. Counselling centres and networks for Roma in the local environment, help of a Roma coordinator, special normatives (number of pupils per class) and standards for the programs designed for adult Romas, free of charge programs and learning aids.

\subsection{Projects Related to the Realisation of the Strategy Goals}

As explained in one of the project, "Roma community differs from the majority in language, culture, traditions, and the question is how much and in what way the present educational system takes this diversity into account [6]. Many research studies exposed that the most frequent reasons for lower schools success of Roma children were as follows: ${ }^{19}$

- Inadequate forms (for example homogenous classes) of inclusion of Roma children in primary school system,

- Teachers are not adequate qualified to deal with specificities of Roma children,

- Low expectations regarding the school results of Roma children, ${ }^{20}$

- $\quad$ Stigmatising of Roma children from the part of the majority children, ${ }^{21}$

- Ignorance or low command of the Slovene language,

- Non-attendance of classes,

- Non-encouraging domestic conditions, ${ }^{22}$

\footnotetext{
${ }^{19}$ More on this: 10 . Krek J, Vogrinc J. Znanje slovenskega jezika kot pogoj šolskega uspeha učencev iz jezikovno in kulturno različnih ter socialno depriviligiranih družin - primer začetnega opismenjevanja romskih učencev. Available from http://ww.ceps.pef.uni-lj.si/2005-krek-vogrinc.pdf 2005. [May 30, 2009].

${ }^{20}$ At the primary school education level in the past lower standards were set for Roma pupils. At the completion of primary school Roma children achieved 6th or 7 th grade knowledge standards. This, however, made inclusion into more demanding forms of education (secondary) impossible. With the introduction of 9-year primary school, knowledge standards for Roma children are the same as for the others.

${ }^{21}$ In many Roma families, housing and hygiene conditions are bad, therefore some children come to school improperly groomed which makes them a target of ridicule and ignorance [12].

${ }^{22}$ In 1991 an extensive longitudinal research study on Roma environment and school success of Roma children in primary schools of Prekmurje was carried out. 411 Roma pupils were included. Analyzed was: domestic environment (living conditions, housing, own room, own bed ...); working
}

- $\quad$ Education does not rank high amongst the values of some Roma parents,

- Distrust of Roma parents towards school, poor participation of Roma parents in the schoolwork processes [6].

Numerous national and school projects are being executed following the Strategy's guidelines. In this study only some of them, namely those related to the Romani language shall be exposed.

\subsubsection{Relevant National Projects}

1. One of the important research projects designed with an aim to realise one of the Strategy's goals is related to the Romani language planning. In the project financed by the Ministry of education and sport of the $\mathrm{RS}$, a vocabulary and a grammar of Romani language, were prepared in order to facilitate the language problems of the Roma children in school [13]. Since Romani, spoken in the Dolenjska and Prekmurje region, belong to two separate Romani dialects which differ substantially with regard to the lexical as well as the syntactic level, separate vocabulary and grammar were prepared for each region.

2. The evaluation of the work of the Roma assistants, as special help to language and social problems of the Roma pupils and a possible solutions to higher percentage of completing the primary education, was the goal of the target research project in which all Roma assistants in Slovenia, their teaching coworkers (teachers) and the principals at school were interviewed.

3. An action research was carried out by mentoring and monitoring the success of integration of Roma children through evaluation of the work of the Roma assistants, introducing anti-bias programs for teachers and attitude assessment of the Roma and non-Roma parents [14].

As stated in the evaluation of this longitudinal research in which data were collected in two panels, the findings and recommendations were the following [15].

"Findings from this evaluation show that responses of the environment are positive towards integration; however the answers themselves suggest existence of ethnical distance towards Roma children. Most participants consider that Roma children education is of major importance as a means for conflict management and for a smoother social integration of the Roma population. With regard to the expectations about the achievement we believe that there has been

conditions for studying at home (electricity); cultural standard (TV, radio, printed media); parents' education, parents' profession, parents' employment. A wholesome insight into domestic social environment of Roma pupils in Prekmurje leads to understanding of big, and often insurmountable problems Roma pupils are facing in primary school. The climate in school often prevents them from equal participation in learning process, as they enter school with far lesser knowledge and realize at the very beginning that their chances to compete with non-Roma fellow students are very small. School practice shows and confirms that as a rule the share of Roma pupils who manage to advance from grade to grade without repetition is low. 
a phase of greater reality awareness. By that we would explain doubts of executive staff, teachers etc. that were not so strongly present in the previous evaluation.

The attendance of Roma children is more frequent now, but is still irregular. Research showed that engaging children in pre-school program influences more regular attendance later in primary school and accelerates their development. Judging by collected data, most of the children had shown balanced developmental progress. Schools have offered extra curricular activities also to Roma children.

Progress of teachers' quality according to ISSA and RWCT standards is evident, although substantial individual differences still exist. It was also concluded that children's progress is quicker when a highly qualified teacher is teaching them. With regard to this finding, special attention should be paid to professional development of teachers in future.

Although the project has many positive effects and Roma children are responding positively, there are still problems with many Roma parents who rarely feel the need to cooperate with school and engage their children regularly. It is interesting, though not surprising, that Roma parents do not want Romany language in curriculum, but they approve the statement that other children should be acquainted with Roma culture and tradition. The role of Roma assistants at cooperation with Roma parents, Roma community and school did not strengthen with regard to the previous evaluation. It was asserted that Roma assistants have a very important effect on children as well as teachers, helping them actively in the classroom. They have a special role with regards to Roma language, culture and tradition. Evident progress of multiculturalism and bilingualism in classrooms can be attributed to their cooperation.

There are many positive impacts of the project stated by the head teachers such as starting to deal with Roma issue systematically, higher quality of teaching etc. On the other hand, in order for the integration to be successful, many things outside the school need to be paid special attention to in the future, such as: linking all institutions dealing with the Roma issue at local and national level, regulate the status of Roma assistants etc."

4. The ECMI final report on Slovenia shows similar outcomes and points to the important role of parents in communication with the educational institutions which is an important drive for a better inclusion of Roma children in schools as well as for a reduction of the drop-out share [6]. Inclusion of Roma children at the earliest age into kindergartens seems to accelerate later inclusion in schools. Owing to the teachers' experiences and the empirical findings the integration of Roma children into kindergartens depends on the following measures:

Active contacts with parents. Contacts should be established before child's entry into kindergarten. Necessary are visits of teachers at a child's home and visits of parents in kindergartens. Teachers should gain parents' trust through positive communication, and by organizing different forms of social meetings.

- Teachers should be especially attentive to the acceptance of Roma children by other children. Instead of emphasizing differences, they should direct children into understanding the benefits of diversity and the advantages of socializing with people of different ethnic, religious and cultural backgrounds.

- Introduction of Roma assistants - this post has not been systemized yet. However, the experience with Roma speaking teachers has been favourable. Roma assistant originating from the Roma community could contribute to easier inclusion of Roma children into kindergarten. He/she could help establish a contact between teachers and Roma children, between Roma and non-Roma children and between kindergarten and Roma parents.

- Permanent education of preschool teachers for the work with Roma children or children of minority communities, and elimination of prejudice and stereotypes, about other ethnic communities [6]: p.85).

5. The project Roma in the process of European integration/ development of models for education and professional training of Roma for increasing of regular employment focused on the international standards in the areas of employment, education and fight against discrimination [16]. Some positive experiences and recent developments in the neighbouring countries are presented in the report, which are relevant for the process of shaping the appropriate models for professional training and employment of Roma in Slovenia.

Various studies and reports of international organizations and national NGO indicate that the position of Roma communities in Slovenia in the field of employment remains insufficient and that majority of unemployed Roma did not finish even elementary school. Two workshops were held in the area of Novo Mesto, where the Roma community resides, in order to promote social inclusion and to improve mutual understanding in the area. Participants were national and international experts, representatives of Roma communities, representatives of local employment services, representatives of social care services, representatives of authorities and some project managers. At the first workshop, which was organized in the year 2001 within the regional/Council of Europe/ project aimed to improve the employment possibilities for Roma in the countries of Central and Eastern Europe, important practical initiatives were indorsed aiming to improve efficiency of the work of local employment services. In order to promote Roma integration and to facilitate mutual contacts, after the workshop, two local employment offices employed two Roma as coordinators /consultants/. They were appointed in the areas of Novo Mesto and Murska Sobota, where the majority of traditionally settled Roma in Slovenia live.

\subsubsection{School Projects}


It is important to underline the role of Roma Community Council in the Republic of Slovenia in the school projects. Namely, it is in cooperation with the Roma Community that school programs are prepared.

A number of projects related to the inclusion of Roma children into education are being executed in schools with integrated Roma pupils. Most of them are consecrated to good practices of inclusion of the Roma children into education: searching of appropriate ways, individual approach, simultaneous evaluation, consideration of the Roma way of life and culture, continuous contact and cooperation with parents work with the Roma assistants.

A three years project Efficient inclusion of Romas into education, financed from the European social fund is consecrated to the Roma assistants. The project is executed by the Roma Association of Slovenia together with schools in Prekmurje and Dolenjska region, Maribor an Kočevsko that integrate Roma children. In the school year (2008/9) there are 31 Roma assistants helping children to adapt and understand the academic contents, and also mediating between the school and the Roma community and also enabling their communication.

\section{CONCLUDING REMARKS}

It is possible to conclude that Slovenia has prepared a sensible framework and constructive strategic approach to alleviate the social inclusion problems of the Roma children in education and of the Roma population in society. The fact that the Roma children are integrated into the mainstream classes, where attention and care for the respect and consideration of their language and culture particularities is manifested by the presence of the Roma assistants, is of special importance for their drop-out reduction and hence for a more effective inclusion of Roma children into education and into the wider society later on. However for the strategic goals, to achieve their full effect, necessary tactical approaches, (relevant for inclusion into education also of children from other vulnerable groups) should be developed and applied in the following areas of practice:

- Measures and priority tasks accepted by different documents should be adequately developed and prepared for all levels of education;

- $\quad$ Programmes for Roma (and migrant) children/pupils prepared by National Education Institute and the Ministry of Education and Sport should be included in the obligatory programmes of the schools at all levels. The financing of these programmes should be guaranteed by the state;

- $\quad$ Permanent education for teachers (lectures, one day workshops, presentations of different experiences and good practices) developing their intercultural awareness, along with specialist qualification (modern methodical and didactic approaches to the L1 and L2 teaching, modern interaction in class, etc.) should become a regular practice in the schools at all levels;

- Inclusion of parents into the school work and communication with them about different inclusion issues should be strengthened and special anti-bias programmes (workshops) need to be prepared;
- In the process of prevention of segregation and selfsegregation, the representatives of the affected communities play a decisive role as mediators in communication between parents and school;

- Cooperation of teachers, pupils, parents, social workers has to be improved;

- The meaning and the significance of inclusion of vulnerable groups into education should be explained also to all parents, also those from the majority population;

- With an aim to diminish the ethnic and social distance which certainly, although indirectly, also affect the results of the vulnerable groups' inclusion into education, schools should prepare lectures on effective struggle against discrimination and anti-bias programs for parents and local population.

- A more systematic approach to education and sensitising of all concerned populations from kindergarten onwards is necessary. Knowledge about and acceptance of cultural and language pluralism as an opportunity, challenge and source of creative potential should be spread on all levels of education and among everybody concerned, pupils, teachers, parents, community representatives and local population.

- Several out-school programmes realized by nongovernmental organizations of substantial value should be supported and also (co)financed;

- The existing practice should be permanently evaluated, the results of good practice disseminated and innovation should be supported;

- $\quad$ Follow-up research projects need to be financed.

It is obvious that the language and cultural dimensions are important issues when the social inclusion of the vulnerable groups such as Roma is discussed. On the one hand, cognitive development and academic outcomes are closely connected to a child's competence of the teaching language, on the other the child's mother tongue and cultural affiliation figure as strong factors in his/her identity formation. A number of obstacles has to be surmounted to grant Roma children equal opportunities in education: among activities to achieve this goal Slovenia has put forward the elaboration of the local Romany written language variety for school use, providing teachers with a basic knowledge of the Romany language, application of an appropriate method for acquisition of the second (i.e. teaching) language based on due respect of the first one, educating of the Roma assistants, etc. The most promising approach to improve the Roma children attainment and to diminish their drop out from school turned out to be the intensive communication between the school and their parents through mediation of the Roma representatives and Roma assistants.

As in other minority groups - the realization of the right of the Roma population to use their language and foster their cultural identity can be achieved through different paths. It is evident, however, that it would be fulfilled only to a limited degree, had their culture and language not been paid a 
special attention from the very beginning of the secondary socialisation of the Roma children, i.e. from the kindergarten onwards. Namely, even more than with other minority groups, proper intergenerational transfer of the Romany language and culture can be achieved only by a substantial support of the wider society. The same is true of their right to develop appropriate second, i.e. the majority language competence as an important instrument of their social integration and promotion.

\section{ACKNOWLEDGEMENT}

We express our deep appreciation and thanks to our colleague and friend, Dr. Geroge Muskins for his initiative and excellent coordination as the head of the EU Commission's Project Inclusion and Education in European Countries.

\section{CONFLICT OF INTEREST}

None declared.

\section{REFERENCES}

[1] Nećak Lük A. Language education policy in Slovenia. Ljubljana: Ministry of Education, Science and Sport, Education Development Unit 2003.

[2] Nećak Lük A, Knaflič L, Novak Lukanovič S. Pluricultural \& plurilingual environment and the School. Research project. Ljubljana: Institute for Ethnic Studies 1994 [In Slovenian].

[3] Skutnab KT. Bilingualism or Not. The education of minorities. Clevedon: Multilingual Matters 1981

[4] Schmidt U. The aspect of culture in the social inclusion of ethnic minorities: assessing language education policies under the EU's open method of coordination, available from http://www.ecmi.de/jemie/download/1-2007_Schmidt.pdf. Flensburg: ECMI; 2007.

[5] Barle LA. Education system in Slovenia 2003/2004, Available from

http://www.mss.gov.si/fileadmin/mss.gov.si/pageuploads/ministrst vo/eng doc/zlozenka-reding-2003.pdf. Ljubljana: Ministry of Education and Sport; 2003.
[6] Žagar M, Komač M, Medvesek M, et al. The aspect of culture in the social inclusion of ethnic minorities : Evaluation of the impact of inclusion policies under the open method of co-ordination in the European union: assessing the cultural policies of six member states. Final report. Slovenia. Flensburg, Ljubljana: European Center for Minority Issues - ECMI, Institute for Ethnic Studies 2006.

[7] Janko SA. Cultural and political construction of Romani ethnic differences in Romological discourse on Roma in Slovenia Anthropol East Eur Rev. 2004;22(2):54-64.

[8] Brezovshek M. Solving the Roma problematics in Slovenia with an accent on the social inclusion of Roma into the education system: final report. Ljubljana: Univerza v Ljubljani, Fakulteta za družbene vede, Inštitut za družbene vede, Center za politološka raziskovanja 2008 [In Slovenian].

[9] Vocational informing and advising for Roma - PISR. In: Žagar N, Klopčič V, Eds. Črnomelj: Institute for Education and Culture 2006.

[10] Krek J, Vogrinc J. Knowledge of Slovenian language as a condition of the school success of students from linguistically and culturally different and socially disadvantaged families - such as the initial literacy of Roma students. Available from http://ww.ceps.pef.unilj.si/2005-krek-vogrinc.pdf 2005 [In Slovenian].

[11] Strategy for education of the Roma in the Republic of Slovenia 2004 [In Slovenian].

[12] TANCER M. Education of Roma in Sloveni]. In: Klopčič V, Polzer M, Eds. Europe, Slovenia and the Roma. Ljubljana: Institute for Ethnic Studies; 2003 [In Slovenian].

[13] KREK J, ANTAUER Ž, CECH P. Project: Standarization of the Roma language and inclusion of Roma culture in education. Ljubljana: Faculty of Education, Center for the Study of Educational Policy; 2006 [In Slovenian].

[14] Vonta T, Rutar S, Balič F, et al. Granting equal opportunities for education of the Roma children]. External evaluator Nećak Lük A, Ed. Ljubljana: Pedagogical Instute; 2005 [In Slovenian].

[15] Nečak Lük A, Brenjc M, Vonta T. Integration of Roma children into mainstream education in Slovenia: SI REI final research and evaluation report. Ljubljana; 2005.

[16] Klopčič V. Roma in the process of European integration/ the development of educational models and Roma qualification for increasing the regular employment. Report. Ljubljana:Institute for Ethnic Studies; 2004 [In Slovenian]. 